\title{
Influences of Moisture Content on Resilient Modulus of Unbound Crushed Limestone
}

\author{
Chanpheng Phommavone ${ }^{1, a}$ and Boonchai Sangpetngam ${ }^{2, b, *}$ \\ 1 Department of Road-Bridge and Transport Engineering, Faculty of Engineering, National University of \\ Laos, Vientiane, Laos \\ 2 Infrastructure Management Research Unit, Department of Civil Engineering, Faculty of Engineering, \\ Chulalongkorn University, Bangkok, Thailand \\ E-mail: achanphengp@gmail.com, bboonchai.sa@chula.ac.th (Corresponding author)
}

\begin{abstract}
The design method of pavement structure is evolving to the new MechanisticEmpirical (M-E) approach. A major benefit of M-E approach is being able to identify the distress patterns and the progress rate of a given pavement structure. This is possible by the knowledge of mechanistic characteristics of pavement materials responding to the repeated loads and environmental changes. Resilient modulus of the unbound granular material is the fundamental parameter needed in the mechanistic analysis of pavement structure. The resilient modulus behavior responding to moisture changes is the key contribution to the structural strength of conventional pavement in Thailand. This study investigated the resilient modulus of the road base materials for the M-E approach. In this research, a set of laboratory tests were conducted on unbound crushed limestone. Two gradations of the limestone were selected to determine the resilient modulus using the repeated-load tri-axial test according to AASHTO T307. Test results revealed that water content played a significant influence to the resilient modulus value. The resilient modulus characteristic of limestone UGM observed from these tests can be employed in Mechanistic-Empirical Pavement Design.
\end{abstract}

Keywords: Unbound granular material, resilient modulus, moisture, mechanistic-empirical pavement design.

ENGINEERING JOURNAL Volume 22 Issue 4

Received 17 January 2018

Accepted 6 June 2018

Published 31 July 2018

Online at http://www.engj.org/

DOI:10.4186/ej.2018.22.4.39 


\section{Introduction}

Unbound granular material (UGM), or known as water bound granular material, is the common material choice for constructing base and subbase layers of low to medium traffic-volume roads in Thailand. Amongst the three rock types i.e. limestone, basalt, granite, limestone is the largest in amount of usage due to the number of quarries throughout the country while basalt and granite are only available in a few sub regions. Since Thailand has a long rainy season and most of low traffic-volume roads are not well elevated above the surrounding flood level, such conditions are favor for moisture presence in UGM layer(s) and may reduce the structural strength of asphalt pavement $[1,2]$.

Resilient modulus $\left(\mathrm{M}_{\mathrm{R}}\right)$ is the most commonly used parameter that describes stiffness of granular materials. It is a measure of the degree to which a material can recover from stress level induced by the traffic load. In other words, $\mathrm{M}_{\mathrm{R}}$ is the elastic modulus based on the recoverable strain under repeated loads. For a repeated load test with constant confining pressure, the resilient modulus is defined as the ratio of the peak axial repeated deviator stress to the peak recoverable axial strain of the specimen. [3]

$$
\mathrm{M}_{\mathrm{R}}=\frac{\left(\sigma_{1}-\sigma_{3}\right)}{\varepsilon_{1}}=\frac{\sigma_{\mathrm{d}}}{\varepsilon_{\mathrm{d}}^{\mathrm{r}}}
$$

where

$\mathrm{M}_{\mathrm{R}}=$ resilient modulus,

$\sigma_{1}=$ major principal or axial stress,

$\sigma_{3}=$ minor principal or confining stress,

$\sigma_{\mathrm{d}}=$ deviator stress,

$\varepsilon_{1}=$ major principal or axial resilient strain, and

$\varepsilon_{d}^{r}=$ axial resilient strain.

Many pavement design guides [3-6] have accepted the resilient modulus as a key parameter to represent the structural characteristic of UGM layer(s). For Thailand, the Department of Highways (DOH) has also adopted the resilient modulus as a parameter for designing a new pavement and evaluating the existing roads for more than a decade [7].

Regarding to the influences of moisture presence in UGM layer(s), many researchers [8-14] found that moisture have a significant influence on the resilient modulus of UGMs. Some recent and interesting findings are summarized as follows.

Lekarp et al. [8] indicated that resilient responses of dry and partially saturated granular materials were similar. A light amount of water content created negative suction pressure which increased the effective stress to the UGM specimens and resulted in higher resilient modulus. On the other hand, the saturated UGM specimens developed excess pore-water pressure under the application of repeated loads. As pore-water pressure developed, the effective stress in the specimens decreased with a subsequent decrease in both strength and modulus of the material.

Magnusdottir and Erlingsson [9] found that a total collapse of specimen could be happened during a resilient modulus test. It happened to some specimens of which the water contents nearly reached the full degree of saturation.

Ekblad and Isacsson [10] investigated the influence of water on resilient properties of unbound crushed granite specimens using four different gradation curves. Upon increasing of water content, the well graded and the finer graded specimens responded with a significant loss of resilient modulus, while the coarsest graded specimens experienced only a slight reduction. Increasing water content also caused increase in Poisson ratio and the specimens became dilative at some situations. This behavior pattern was more pronounced as the gradation became finer.

Bilodeau and Dore [11] attempted to develop a generalized model quantifying water sensitivity of resilient modulus of typical Canadian UGMs used in pavement bases. They found that the model was sensitive to stress state, fine fraction, porosity and aggregate type.

All mentioned findings showed that high water content could significantly lower the UGM load carrying capacity and resulted in pavement damages. The influence of a moisture variation on the resilient modulus of the UGM is quite dependent on aggregate source and grading. Currently there is no generalized model available for local UGMs in Thailand to estimate the resilient modulus upon a water content level. 
The objectives of this study are to obtain the information on the resilient modulus of local limestone UGM and how it is affected by moisture variation from low to high level. In addition, effects of stress condition and gradation will be addressed as well. The results of this study will lead to a better understanding of the pavement responses to moisture in different seasons and more realistic modulus values in the pavement design parameter for UGM base and subbase layers.

\section{Research Procedure}

\subsection{Specimen Preparation}

In this study, two thousand kilograms of crushed limestone collected from a source in Saraburi province was obtained as a representative UGM. The limestone batch was oven-dried, sieved into various sizes and stored in closed containers. Later on, they were weighed and blended together to meet the specified gradation table. The limestone aggregate was split into two gradation blends to represent the fine and coarse grading sides of the DOH specification. The fine gradation was named G1 and the coarse gradation was named G2. The particle size distribution curves of G1 and G2 are shown in Fig. 1. Both has the same nominal maximum aggregate size of 19.0 millimeters. Their basic properties are listed in Table 1.

Table 1. Summary of basic properties of G1 and G2.

\begin{tabular}{|c|c|c|c|}
\hline Properties & $\begin{array}{c}\text { DOH } \\
\text { Specification[15] }\end{array}$ & $\begin{array}{c}\text { G1 } \\
\text { Fine } \\
\text { graded }\end{array}$ & $\begin{array}{c}\text { G2 } \\
\text { Coarse } \\
\text { graded }\end{array}$ \\
\hline Aggregate type & & $\begin{array}{c}\text { Crushed } \\
\text { Limestone }\end{array}$ & $\begin{array}{c}\text { Crushed } \\
\text { Limestone }\end{array}$ \\
\hline \multicolumn{4}{|l|}{$\begin{array}{l}\text { Particle size distribution (ASTM C136)[16] } \\
\end{array}$} \\
\hline $\mathrm{mm}$ (mesh no.) & \multicolumn{3}{|c|}{$\%$ Passing } \\
\hline $25.0(1 ”)$ & 100 & 100 & 100 \\
\hline $19.0(3 / 4 ”)$ & & 95.5 & 84 \\
\hline $12.5(1 / 2 ”)$ & & 83.5 & 63 \\
\hline 9.5 (3/8”) & $50-85$ & 75.5 & 50 \\
\hline $4.75(\# 4)$ & & 60.5 & 38 \\
\hline $2.00(\# 10)$ & $25-50$ & 43 & 25 \\
\hline $0.425(\# 40)$ & $15-30$ & 23.5 & 15 \\
\hline $0.075(\# 200)$ & $5-15$ & 11 & 5 \\
\hline \multicolumn{4}{|c|}{ Bulk specific gravity (ASTM C127, C128) $[17,18]$} \\
\hline Gsb & & 2.684 & 2.692 \\
\hline \%Water absorption & & 0.67 & 0.55 \\
\hline \multicolumn{4}{|l|}{ Modified compaction test (ASTM D1557)[19] } \\
\hline Optimum water content (OWC) (\%) & & 4.8 & 4.4 \\
\hline Maximum dry density (MDD) $\left(\mathrm{g} / \mathrm{cm}^{3}\right)$ & & 2.35 & 2.42 \\
\hline \multicolumn{4}{|l|}{ California Bearing Ratio (ASTM D1883)[20] } \\
\hline \%CBR@95\% MDD (\%) & $\geq 25$ & 95 & 129 \\
\hline
\end{tabular}

In preparing an UGM specimen for resilient modulus test, the amount of blended aggregate was weighed based on a desired dry density at 95\%MDD and the cylindrical mold volume of $100 \mathrm{~mm}$ diameter $\mathrm{x} 200 \mathrm{~mm}$ height. The dry material was mixed thoroughly with an amount of water to meet the target water content and was stored in a closed plastic bag overnight. Then it was compacted using vibratory hammer compaction according to AASHTO T307-99 [21]. The dimension and weight of the specimen after extrusion from the mold were recorded for moisture and density calculation. The final preparation step was to fit a rubber membrane around the specimen, then assembled the upper chamber of tri-axial cell and placed the cell into the testing position. 


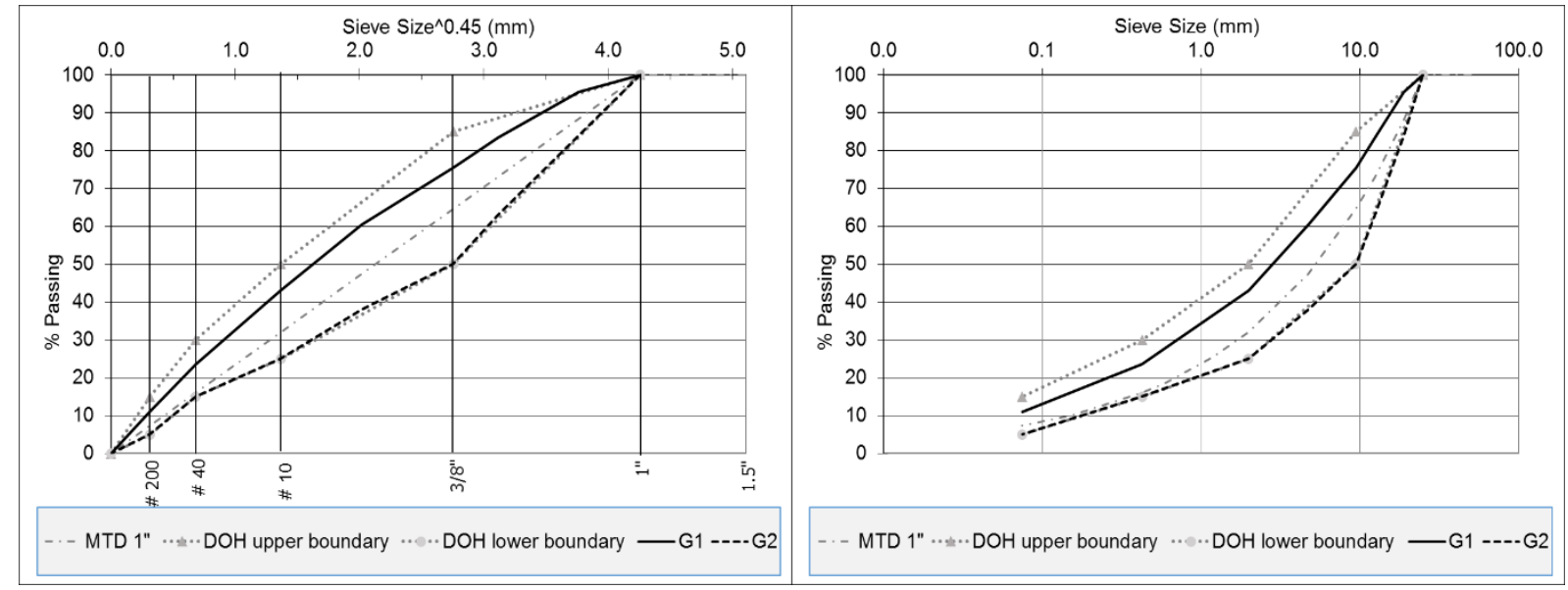

Fig. 1. Gradation graphs of G1, G2, DOH specification and Maximum Theoretical Density (MTD) line.
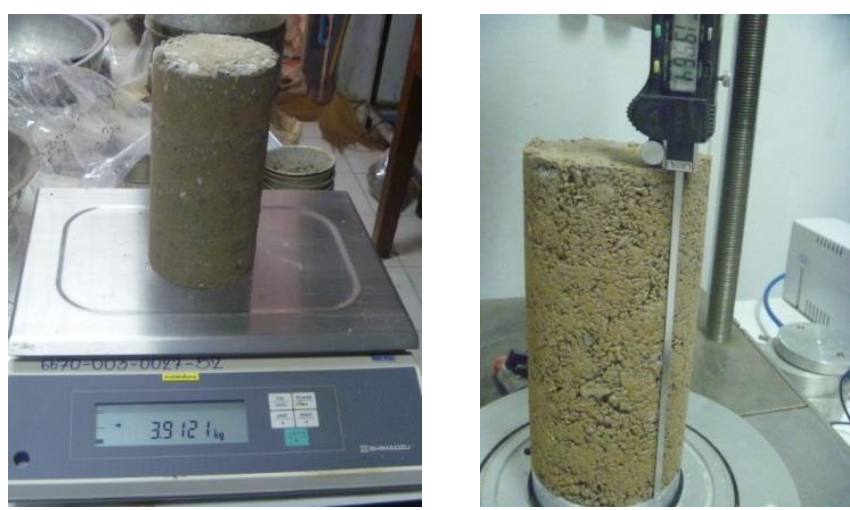

Fig. 2. Weighting compacted sample (Left), compacted sample size measurement (Right).

\subsection{Resilient Modulus Test}

The resilient modulus test procedure was conducted by following AASHTO T307-99 testing standard [21]. The tested material was classified as base/subbase material according to the testing standard. Each specimen was set to undergo 15 loading sequences of various deviatoric and confining stresses as presented in Table 2 . However, a few specimens had collapsed before completing the $15^{\text {th }}$ sequence due to the strength reduction. The collapse was also founded by Magnusdottir and Erlingsson [9]. After completion of resilient modulus test, the specimen's moist weight and oven-dried weight were measured for determining the actual water content and dry density of the specimen.
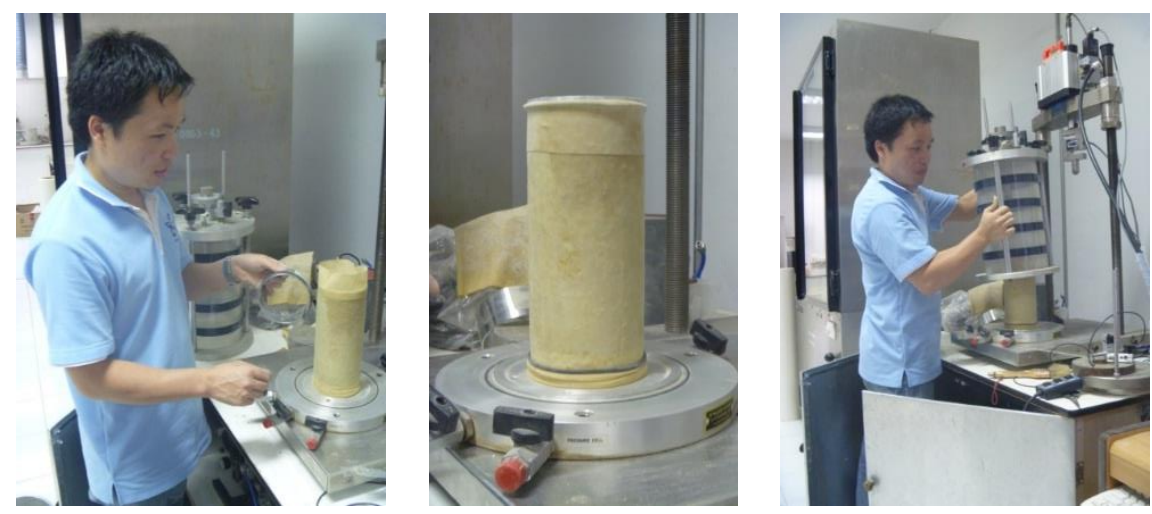

Fig. 3. Fit the rubber membrane (left), the sample ready to test (middle), assembly tri-axial cell (right). 
Table 2. Testing sequences for base/subbase materials [21].

\begin{tabular}{|c|c|c|c|c|c|}
\hline $\begin{array}{c}\text { Sequence } \\
\text { No. }\end{array}$ & $\begin{array}{l}\text { Confining } \\
\text { pressure } \mathrm{S}_{3} \\
(\mathrm{kPa})\end{array}$ & $\begin{array}{c}\text { Max axial } \\
\text { stress } S_{\text {max }} \\
\quad(\mathrm{kPa})\end{array}$ & $\begin{array}{c}\text { Cyclic stress } \\
\mathrm{S}_{\text {cyclic }} \\
(\mathrm{kPa})\end{array}$ & $\begin{array}{c}\text { Constant } \\
\text { stress 0.1S } \\
(\mathrm{kPa})\end{array}$ & $\begin{array}{l}\text { Number of } \\
\text { load } \\
\text { applications }\end{array}$ \\
\hline 0 & 103.4 & 103.4 & 93.1 & 10.3 & 500 \\
\hline 1 & 20.7 & 20.7 & 18.6 & 2.1 & 100 \\
\hline 2 & 20.7 & 41.4 & 37.3 & 4.1 & 100 \\
\hline 3 & 20.7 & 62.1 & 55.9 & 6.2 & 100 \\
\hline 4 & 34.5 & 34.5 & 31.0 & 3.5 & 100 \\
\hline 5 & 34.5 & 68.9 & 62.0 & 6.9 & 100 \\
\hline 6 & 34.5 & 103.4 & 93.1 & 10.3 & 100 \\
\hline 7 & 68.9 & 68.9 & 62.0 & 6.9 & 100 \\
\hline 8 & 68.9 & 137.9 & 124.1 & 13.8 & 100 \\
\hline 9 & 68.9 & 206.8 & 186.1 & 20.7 & 100 \\
\hline 10 & 103.4 & 68.9 & 62.0 & 6.9 & 100 \\
\hline 11 & 103.4 & 103.4 & 93.1 & 10.3 & 100 \\
\hline 12 & 103.4 & 206.8 & 186.1 & 20.7 & 100 \\
\hline 13 & 137.9 & 103.4 & 93.1 & 10.3 & 100 \\
\hline 14 & 137.9 & 137.9 & 124.1 & 13.8 & 100 \\
\hline 15 & 137.9 & 275.8 & 248.2 & 27.6 & 100 \\
\hline
\end{tabular}

\subsection{Experimental Cases}

For experimental design, the specimen preparation was targeted to vary on water contents ranging from the dry side to the optimum water content to allow for statistical analysis of the influencing parameter. For gradation G1, 3 targeted levels of 2.0\%, 3.4\%, 4.8\% were prepared. For gradation G2, 3 targeted levels of water contents of $2.0 \%, 3.2 \%, 4.4 \%$ were prepared. Table 3 summarizes the targeted conditions of specimen preparation. The properties of all specimens after compaction were determined and summarized in Table 4 , 5,6 .

Table 3. Target conditions of specimen preparation.

\begin{tabular}{ccccc}
\hline Case & Gradation & \%Water content & Repetition & $\begin{array}{c}\text { Number of } \\
\text { specimens }\end{array}$ \\
\hline 1 & G1 (fine-graded) & $2.0,3.4,4.8$ & 3 & 9 \\
\hline 2 & G2 (coarse-graded) & $2.0,3.2,4.4$ & 3 & 9 \\
\hline
\end{tabular}

The void ratio (e) and \%saturation were calculated using the following definitions and equations [22].

$$
\begin{aligned}
& \text { Void ratio, e }=\left(\mathrm{G}_{\mathrm{sb}} * \gamma_{\mathrm{w}} / \gamma_{\mathrm{d}}\right)-1 \\
& \% \text { saturation }=(\% \mathrm{w} * \mathrm{Gsb}) / \mathrm{e}
\end{aligned}
$$

where

$\gamma_{\mathrm{w}}=$ density of water

$\gamma_{\mathrm{d}} \quad=$ dry density of compacted specimen

$\mathrm{G}_{\mathrm{sb}}=$ bulk specific gravity of aggregate

$\mathrm{w}=$ water content of material

$\mathrm{e} \quad=$ void ratio of compacted specimen

The actual water content of specimen was determined after compaction. The results show that the specimens of both gradation were prepared close to the targeted \%water content. The average compaction level was $98.9 \% \mathrm{MDD}$ for $\mathrm{G} 1$ and $99.3 \% \mathrm{MDD}$ for $\mathrm{G} 2$. 
Table 4. Details of G1 specimens after compaction.

\begin{tabular}{ccccccc}
\hline $\begin{array}{c}\text { Targeted } \\
\text { water content }\end{array}$ & $\begin{array}{c}\text { replicate } \\
\text { no. }\end{array}$ & $\begin{array}{c}\text { Actual water } \\
\text { content }\end{array}$ & $\begin{array}{c}\text { Dry density } \\
\left(\mathbf{g} / \mathbf{c m}^{\mathbf{3}} \mathbf{)}\right.\end{array}$ & $\begin{array}{c}\text { Void } \\
\text { ratio, } \mathbf{e}\end{array}$ & \%saturation & $\begin{array}{c}\text { Compaction } \\
\text { \%MDD }\end{array}$ \\
\hline 2.0 & 1 & 2.18 & 2.234 & 0.202 & 29.1 & 95.0 \\
\hline 2.0 & 2 & 1.96 & 2.265 & 0.185 & 28.4 & 96.4 \\
\hline 2.0 & 3 & 2.2 & 2.284 & 0.175 & 33.7 & 97.2 \\
\hline 3.4 & 1 & 3.55 & 2.297 & 0.169 & 56.5 & 97.7 \\
\hline 3.4 & 2 & 3.58 & 2.307 & 0.163 & 58.8 & 98.2 \\
\hline 3.4 & 3 & 3.4 & 2.369 & 0.133 & 68.5 & 100.8 \\
\hline 4.8 & 1 & 4.51 & 2.329 & 0.153 & 79.2 & 99.1 \\
\hline 4.8 & 2 & 4.55 & 2.413 & 0.112 & 108.7 & 102.7 \\
\hline 4.8 & 3 & 4.2 & 2.425 & 0.107 & 105.4 & 103.2 \\
\hline
\end{tabular}

Table 5. Details of G2 specimens after compaction.

\begin{tabular}{ccccccc}
\hline $\begin{array}{c}\text { Targeted } \\
\text { water content }\end{array}$ & $\begin{array}{c}\text { Replicate } \\
\text { no. }\end{array}$ & $\begin{array}{c}\text { Actual water } \\
\text { content }\end{array}$ & $\begin{array}{c}\text { Dry density } \\
\left(\mathbf{g} / \mathbf{c m}^{\mathbf{3}}\right)\end{array}$ & $\begin{array}{c}\text { Void } \\
\text { ratio, } \mathbf{e}\end{array}$ & \%saturation & $\begin{array}{c}\text { Compaction } \\
\text { \%MDD }\end{array}$ \\
\hline 2.0 & 1 & 1.94 & 2.382 & 0.13 & 39.4 & 98.4 \\
\hline 2.0 & 2 & 1.97 & 2.332 & 0.154 & 33.8 & 96.4 \\
\hline 2.0 & 3 & 1.93 & 2.37 & 0.135 & 37.7 & 98.0 \\
\hline 3.2 & 1 & 3.09 & 2.46 & 0.097 & 86.3 & 101.6 \\
\hline 3.2 & 2 & 3.14 & 2.431 & 0.11 & 77.1 & 100.4 \\
\hline 3.2 & 3 & 3.15 & 2.438 & 0.106 & 79.8 & 100.8 \\
\hline 4.4 & 1 & 4.22 & 2.391 & 0.126 & 88.8 & 98.8 \\
\hline 4.4 & 2 & 4.31 & 2.413 & 0.115 & 98.6 & 99.7 \\
\hline 4.4 & 3 & 4.16 & 2.413 & 0.115 & 95.3 & 99.7 \\
\hline
\end{tabular}

Table 6. Summary of G1 and G2 specimens after compaction.

\begin{tabular}{lcccccccccc}
\hline \multirow{2}{*}{ Parameters } & \multicolumn{2}{c}{$\begin{array}{c}\text { \%Water } \\
\text { content }\end{array}$} & \multicolumn{2}{c}{$\begin{array}{c}\text { \%Max Dry } \\
\text { Density }\end{array}$} & \multicolumn{2}{c}{$\boldsymbol{\gamma}$ dry $\left(\mathbf{g} / \mathbf{c m}^{3}\right)$} & \multicolumn{2}{c}{ Void ratio (e) } & \multicolumn{2}{c}{ \%saturation } \\
& G1 & G2 & G1 & G2 & G1 & G2 & G1 & G2 & G1 & G2 \\
\hline N & 9 & 9 & 9 & 9 & 9 & 9 & 9 & 9 & 9 & 9 \\
Average & 3.3 & 3.1 & 98.9 & 99.3 & 2.32 & 2.40 & 0.155 & 0.121 & 63.1 & 70.8 \\
Max & 4.6 & 4.3 & 103.2 & 101.6 & 2.43 & 2.46 & 0.202 & 0.154 & 108.7 & 98.6 \\
Min & 2.0 & 1.9 & 95.1 & 96.4 & 2.23 & 2.33 & 0.107 & 0.097 & 28.4 & 33.8 \\
SD & 1.0 & 1.0 & 2.8 & 1.6 & 0.07 & 0.04 & 0.032 & 0.017 & 30.5 & 26.2 \\
\hline
\end{tabular}

Note that in Table 4 and Table 5, there are some specimens having degree of saturation exceed 100\%. By definition, degree of saturation of a specimen indicates the ratio of volume of water over the volume of voids around aggregate the specimen. It can be determined using Eq. (3). If there is no water absorbed into aggregate pores, degree of saturation cannot exceed $100 \%$. However, if water absorption is presented, then degree of saturation may become greater than $100 \%$. Even though there is some volume of air voids left around the aggregate particles. Based on the bulk specific gravity of aggregate test results presented in Table 1, \%water absorption of G1 and G2 materials are $0.67 \%$ and $0.55 \%$ respectively. During a specimen preparation, the aggregate was mixed with water and left in a sealed plastic bag overnight before the compaction. The specimen had time to absorb some moisture into pores inside the aggregate particles. Therefore, the actual amount of water presented around aggregate particles was less than the water content of specimen. If the specimen water content is deducted by an approximated water absorption, the degree of saturation will not exceed $100 \%$.

In Table 4 and Table 5, there were some specimens having \%compaction slightly exceeded 100\%MDD of modified compaction. It was because the method used in specimen compaction was different than the modified compaction method. The vibratory compaction was used according to AASHTO T307 standard to 
prepare a cylindrical shaped specimen of $100 \mathrm{~mm}$ diameter $\mathrm{x} 200 \mathrm{~mm}$ height. It seems that the vibratory compaction procedure might produce higher compacting energy than the modified compaction method. This resulted in slightly higher dry density in some specimens.

\section{Results and Analysis}

\subsection{Resilient Modulus Test Results}

The results of determining the resilient modulus of samples prepared at the designed values of interested parameters are summarized in graphs shown in Fig. 4 - Fig. 5. These graphs illustrate the averaged resilient modulus from the replicate specimens of the same parameter setting (gradation and \%water content) at 15 loading sequences. Note that the G2 specimens with water contents at $4.4 \%$ underwent instability or failure before reaching the $15^{\text {th }}$ loading stage, therefore the resilient modulus of those specimens were excluded from the graphs. The failure cases happened in the samples with high \%water content and subjected to high stress magnitude in higher loading sequences.

There are few remarks that can be drawn from the graphs:

- $\mathrm{M}_{\mathrm{R}}$ values of the specimens varied in the range of 100 to $500 \mathrm{MPa}$ within the 15 applied stress states.

- All of the $\mathrm{M}_{\mathrm{R}}$ graphs indicated the same evidence that \%water content had a significant influence on the $\mathrm{M}_{\mathrm{R}}$ value for both $\mathrm{G} 1$ and $\mathrm{G} 2$. The lower \%water content, the higher $\mathrm{M}_{\mathrm{R}}$ value.

- At a given \%water content, the $M_{R}$ value increased with the increasing loading sequences. The $M_{R}$ value was dependent on the applied stress state. As the confining stress and deviatoric stress increased, the $\mathrm{M}_{\mathrm{R}}$ value increased as well.

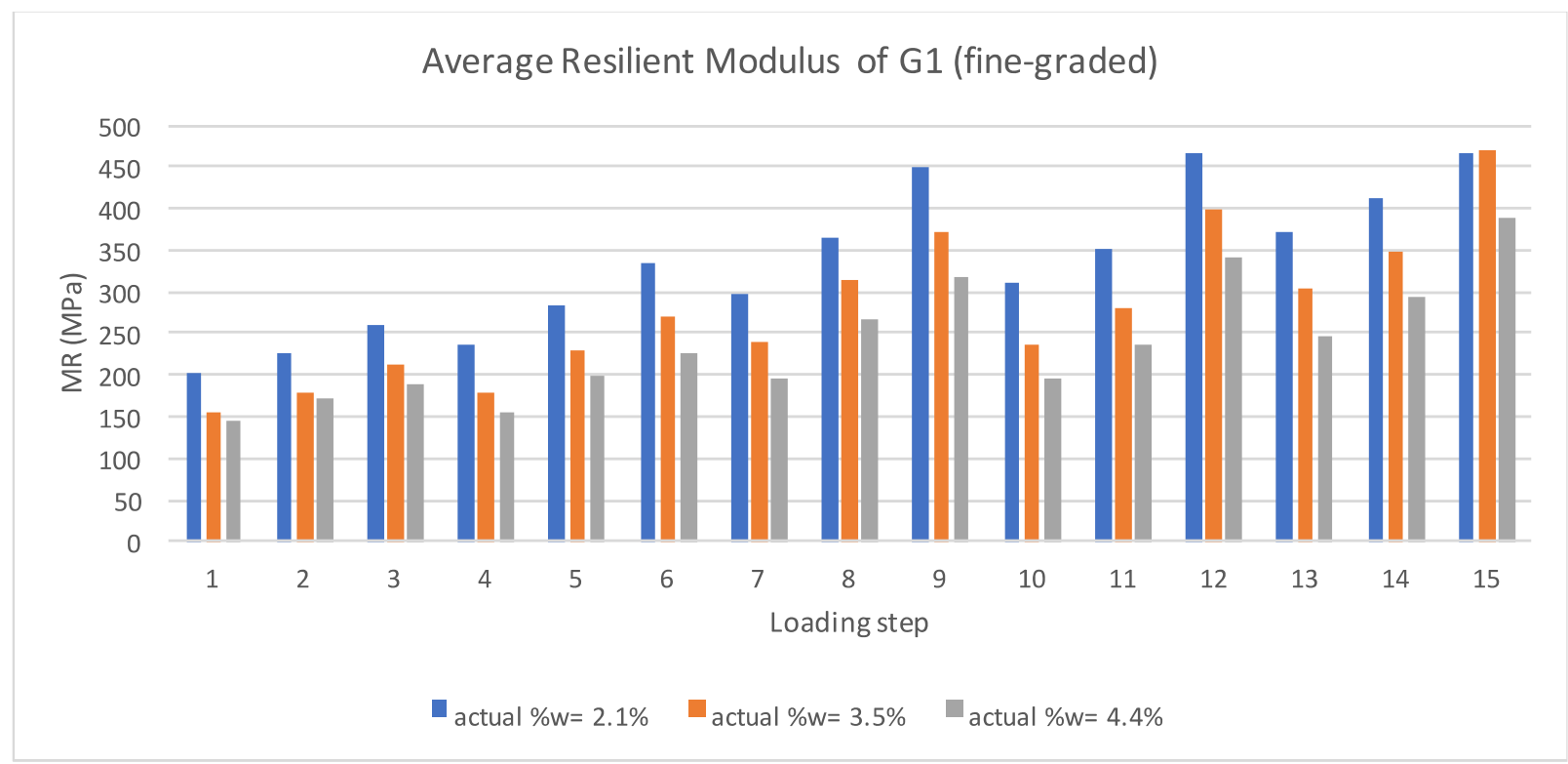

Fig. 4. Resilient modulus of fine graded G1 (Fine Graded). 


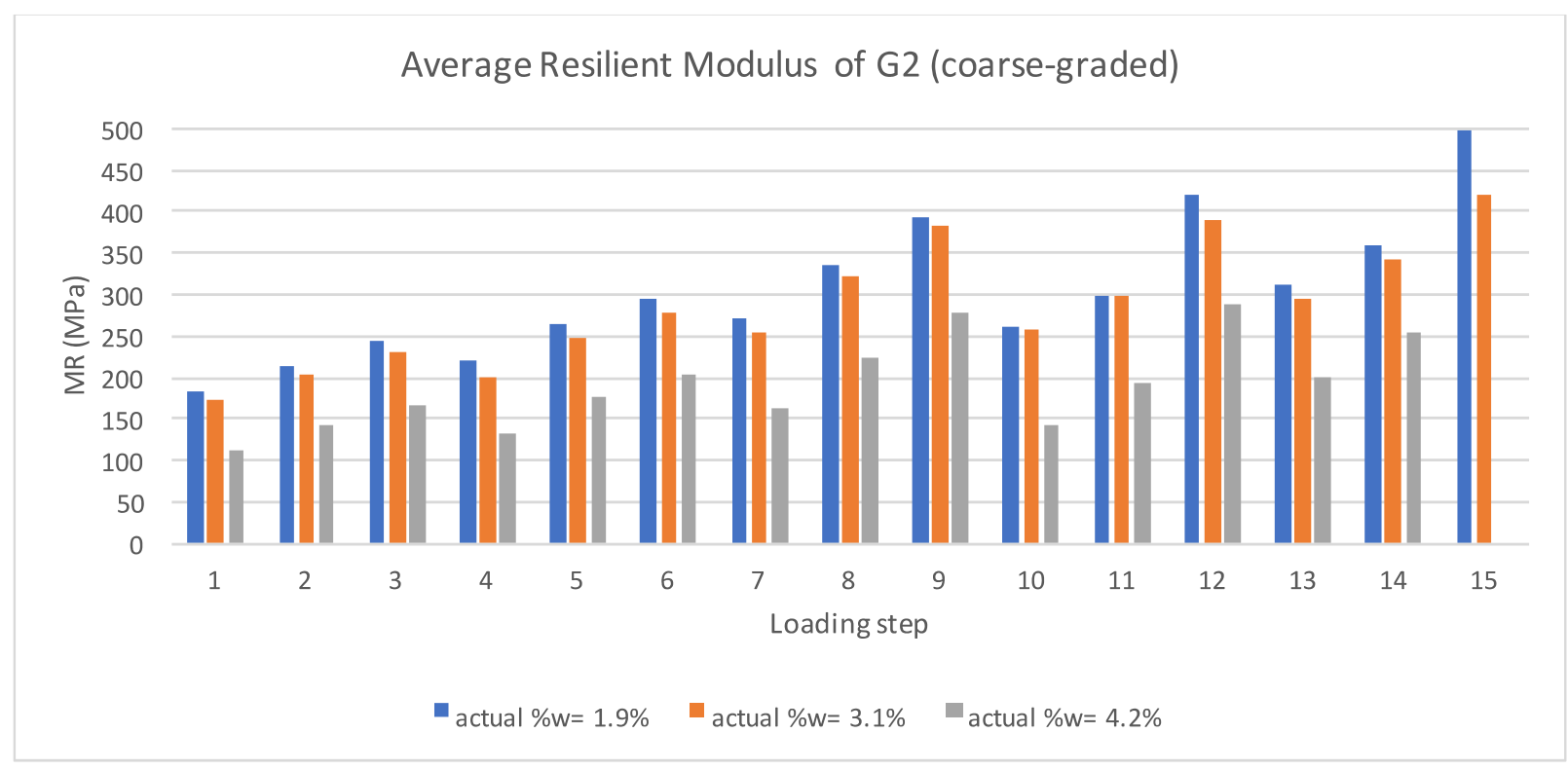

Fig. 5. Resilient modulus of fine graded G2 (Coarse-Graded).

\subsection{Regression Analysis of Resilient Modulus Model}

Initially, the relationship between resilient modulus and stress state of granular materials was widely accepted in a form of bulk stress equation as presented in Eq.(4) [3, 23, 24]. Later, a general form of the resilient modulus prediction model of UGM was presented in the AASHTO mechanistic-empirical pavement design guide as shown in Eq. (5) [4]. In this study, the water content variable is added into the general $M_{R}$ equation as a hypothesis of the relationship of water content, stress state and resilient modulus. The proposed model is presented in Eq. (6).

$$
\begin{gathered}
\mathrm{M}_{\mathrm{R}}=\mathrm{k}_{1} \theta^{\mathrm{k}_{2}} \\
\mathrm{M}_{\mathrm{R}}=\mathrm{k}_{1} \mathrm{P}_{\mathrm{a}}\left(\frac{\theta}{\mathrm{P}_{\mathrm{a}}}\right)^{\mathrm{k}_{2}}\left(\frac{\tau_{\text {oct }}}{\mathrm{P}_{\mathrm{a}}}+1\right)^{\mathrm{k}_{3}} \\
M_{R}=k_{1} P_{a}\left(\frac{\theta}{P_{a}}\right)^{k_{2}}\left(\frac{\tau_{\text {oct }}}{P_{a}}+1\right)^{k_{3}}(w)^{k_{4}}
\end{gathered}
$$

where:

$$
\begin{aligned}
& \mathrm{k}_{1}, \mathrm{k}_{2}, \mathrm{k}_{3}, \mathrm{k}_{4} \text { are constants } \\
& \mathrm{Pa}=\text { atmospheric pressure }=101.3 \mathrm{kPa} \\
& \theta=\text { bulk stress }=\text { sum of major principal stresses }=\sigma_{1}+\sigma_{2}+\sigma_{3} \\
& \tau \text { oct }=\text { octahedral stress }=\frac{1}{3} \sqrt{\left(\sigma_{1}-\sigma_{2}\right)^{2}+\left(\sigma_{1}-\sigma_{3}\right)^{2}+\left(\sigma_{2}-\sigma_{3}\right)^{2}}
\end{aligned}
$$

Since each independent variable in Eq. (6) is in a form of power to a constant, the revised form of Eq. (6) as proposed in Eq. (9) is the ready form for regression analysis by taking the natural logarithm of Eq. (6). In the stated equation, the bulk stress $(\theta)$ and the octahedral stress ( $\tau$ oct) are determined from the vertical stress $\left(\sigma_{1}\right)$ and the confining stress $\left(\sigma_{3}\right)$. As such, a linear regression analysis is conducted using the $M_{R}$ data of the G1 and G2 specimens.

$$
\begin{array}{r}
\ln \mathrm{M}_{\mathrm{R}}=\ln \left[\mathrm{k}_{1} \mathrm{P}_{\mathrm{a}}\left(\frac{\theta}{\mathrm{P}_{\mathrm{a}}}\right)^{\mathrm{k}_{2}}\left(\frac{\tau_{\mathrm{OCT}}}{\mathrm{P}_{\mathrm{a}}}+1\right)^{\mathrm{k}_{3}}(\mathrm{w})^{\mathrm{k}_{4}}\right] \\
\ln \left(\frac{\mathrm{M}_{\mathrm{R}}}{\mathrm{Pa}}\right)=\operatorname{lnk}_{1}+\mathrm{k}_{2} \ln \left(\frac{\theta}{\mathrm{P}_{\mathrm{a}}}\right)+\mathrm{k}_{3} \ln \left(\frac{\tau_{\mathrm{OCT}}}{\mathrm{P}_{\mathrm{a}}}+1\right)+\mathrm{k}_{4} \ln (\mathrm{w}) \\
\mathrm{y}=\beta_{0}+\beta_{1} \mathrm{x}_{1}+\beta_{2} \mathrm{x}_{2}+\beta_{3} \mathrm{x}_{3}
\end{array}
$$


where:

$$
\begin{aligned}
& \mathrm{y}=\ln \left(\frac{M r}{P_{a}}\right), \mathrm{x}_{1}=\ln \left(\frac{\theta}{P_{a}}\right), \mathrm{x}_{2}=\ln \left(\frac{\tau_{o c t}}{P_{a}}+1\right), \mathrm{x}_{3}=\ln (\mathrm{w}) \\
& \beta_{0}=\ln \left(\mathrm{k}_{1}\right) \quad \beta_{1}=\mathrm{k}_{2} \quad \beta_{2}=\mathrm{k}_{3} \quad \beta_{3}=\mathrm{k}_{4}
\end{aligned}
$$

The results of the linear regression analysis are illustrated in Table 7 including the constants of resilient modulus relationship model and their significant levels from the linear regression analysis. It reveals that the proposed relationship in Eq. (9) is successfully valid by considering the significance output of the four variables in the equation. All four variables have earned the significance level of lower than 0.025 . The analysis gains the adjusted $\mathrm{R}^{2}$ of 0.904 with 134 numbers of data points for Gradation G1 and the adjusted $\mathrm{R}^{2}$ of 0.820 with 121 numbers of data points for Gradation G2. The constants k1 to k4 are presented in Table 7.

Table 7. Summary of $\mathrm{k}$ constants of resilient modulus relationship model.

\begin{tabular}{lllccccc}
\hline \multicolumn{1}{c}{ Gradation } & constants & k1 & k2 & k3 & k4 & Adj. $\mathbf{R}^{2}$ & N \\
\hline G1 & Value & 2673 & 0.137 & 0.991 & -0.451 & \multirow{2}{*}{0.904} & \multirow{2}{*}{134} \\
(fine-graded) & Sig. & 0.000 & 0.000 & 0.000 & 0.000 & & \\
\hline G2 & Value & 2483 & 0.086 & 1.107 & -0.479 & \multirow{2}{*}{0.820} & \multirow{2}{*}{121} \\
(coarse-graded) & Sig. & 0.000 & 0.024 & 0.000 & 0.000 & & \\
\hline
\end{tabular}

The final equations of resilient modulus relationship based on the regression analysis are illustrated in Eq. (10) and (11).

Fine-graded G1,

$$
M_{r}(\mathrm{MPa})=271\left(\frac{\theta}{P_{a}}\right)^{0.137}\left(\frac{\tau_{\mathrm{oct}}}{P_{a}}+1\right)^{0.991}(\% w)^{-0.451}
$$

Coarse-graded G2,

$$
M_{r}(\mathrm{MPa})=252\left(\frac{\theta}{P_{a}}\right)^{0.086}\left(\frac{\tau_{\mathrm{oct}}}{P_{a}}+1\right)^{1.107}(\% w)^{-0.479}
$$

\subsection{Influences of Considering Variables}

\subsubsection{Influence of water content}

From the regression models of Eq. (6), the term containing water content variable is (w) ${ }^{\mathrm{k} 4}$ in which the constant $\mathrm{k} 4$ is negative value for both G1 and G2 specimens. This result confirms that the resilient modulus decreases as \%water content increases. The graphs in Figs. $4-5$ illustrate this evidence.

\subsubsection{Influence of gradation}

Box plots of resilient modulus of G1 and G2 specimens shown in Fig. 6 illustrate a rough comparison between two gradations at three water content levels. In general, G1 graphs are slightly higher than those of G2. However, the resilient modulus of coarse-graded specimens decreases substantially at water content of $4.2 \%$ close to the optimum water content $(4.4 \%)$. 

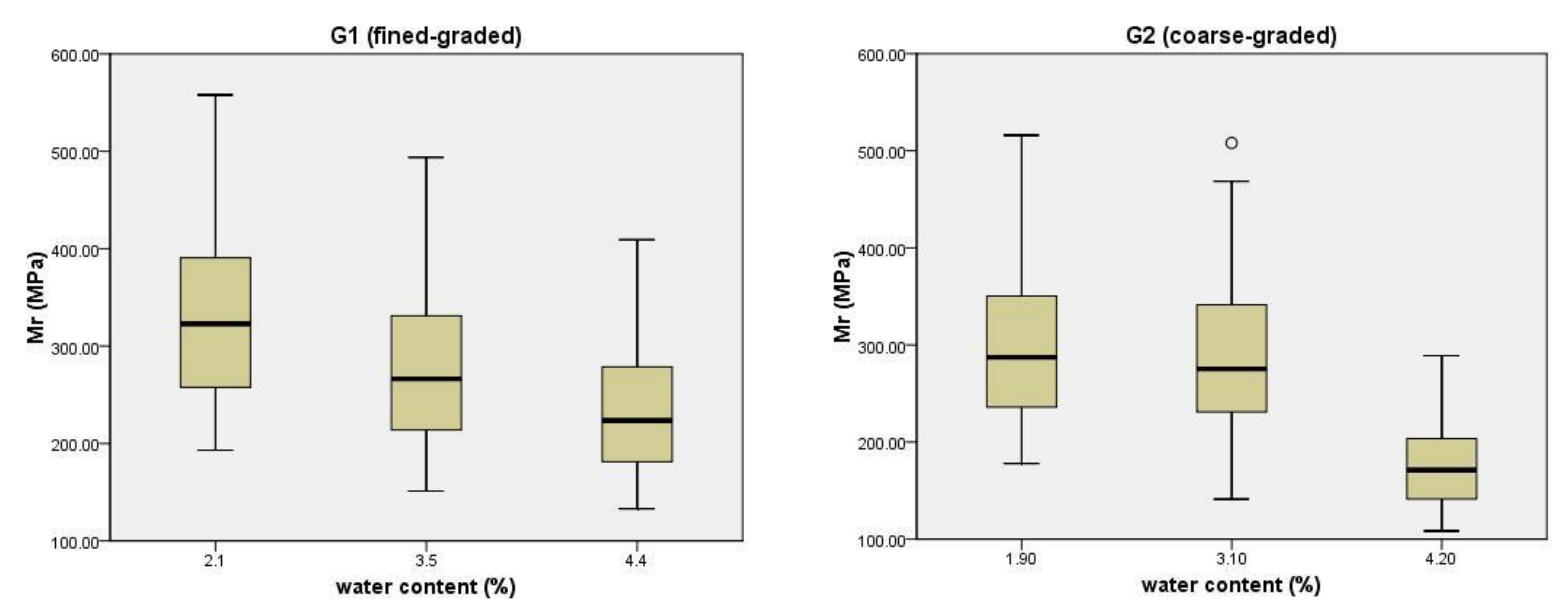

Fig. 6. Box plots of resilient modulus of G1 and G2 at various water contents.

\section{Conclusion}

The resilient modulus characteristic upon the water content of local limestone UGM was studied. The UGM specimens were prepared at two gradation and three water content levels. The resilient modulus tests were conducted on the specimens using the tri-axial repeated load setup.

The findings of this research provide some understanding of the characteristic of the crushed limestone UGM and are greatly benefits to the road base/subbase construction and evaluation in the field as follows.

- The results of regression analysis indicated that the resilient modulus increased significantly as the water content in the UGM reduced from the wet side to the dry side. Though, the optimum water content is the easiest point to compact the UGM to the highest density, it does not provide the highest resilient modulus. Perhaps, the UGM base/subbase layer should be left exposing to the ambient heat to allow some water content reduction for the best mechanistic performance of the constructed pavement.

- The specimens with fine gradation tend to have slightly higher resilient modulus than those with coarse gradation.

- This study has modified the general form of the resilient modulus prediction model of UGM by adding the water content variable into Eq. (5). The final equations based on the regression analysis are presented in Eq. (10) and (11).

\section{Acknowledgements}

We would like to sincerely thank AUN/SEED-Net and the Infrastructure Management Research Unit under the Ratchadaphiseksomphot Fund for the support of this study.

\section{References}

[1] Y. S. Yeo, H. Nikraz, and P. Jitsangiam, "Tube suction test to measure moisture susceptibility of Australian pavements," Engineering Journal, vol. 16, no. 4, pp. 159-168, Jun. 2012.

[2] M. U. Khan, M. Mesbah, L. Ferreira, and D. J. Williams, "A case study on pavement performance due to extreme moisture intrusion at untreated layers," International Journal of Pavement Engineering, 2017. doi: 10.1080/10298436.2017.1408272

[3] American Association of State Highway and Transportation Officials, AASHTO Guide for Design of Pavement Structures. Washington, D.C., 1993.

[4] National Research Council, "Part 2: Design Inputs, Chapter 2 Material Characterization," in Guide for Mechanistic-Empirical Design of New and Rehabilitated Pavement Structures, Final Report, NCHRP Project 1-37 A. TRB. National Research Council, Washington, D.C., March 2004. 
[5] Austroads Incorporated, Guide to Pavement Technology Part 2: Pavement Structural Design. New South Wales, 2010.

[6] The South African National Roads Agency LTD, "Chapter 10 Pavement designs," in South African Pavement Engineering Manual. Gauteng, 2013.

[7] Y. Taesiri and P. Jitareekul, "Pavement Materials," in An Engineering Manual for Highway Pavement Design. Bangkok, Thailand: Department of Highways (DOH), 2002, ch. 3, pp. 9-17.

[8] F. Lekarp, U. Isacsson, and A. R. Dawson, "Permanent strain response of unbound aggregates," Transportation Engineering, pp. 76-84, 2000.

[9] B. Magnusdottir and S. Erlingsson, "Repeated load triaxial testing for quality assessment of unbound granular base course material," in Proceedings of the 9th Nordic Aggregate Research Conference, Reykjavik, Iceland, 2002.

[10] J. Ekblad and U. Isacsson, "Influence of water on resilient properties of coarse granular materials," Road Materials and Pavement Design, pp. 369-404, 2006.

[11] J. P. Bilodeau and G. Doré, "Water sensitivity of resilient modulus of compacted unbound granular materials used as pavement base," International Journal of Pavement Engineering, vol. 13, no. 5, pp. 459-471, 2012. doi: 10.1080/10298436.2011.573556

[12] S. Erlingsson, "Impact of water on the response and performance of a pavement structure in an accelerated test," Road Materials and Pavement Design, vol. 11, no. 4, pp. 863-880, 2010.

[13] M. Ba, M. Fall, F. Samb, D. Sarr, and M. Ndiaye, "Resilient modulus of unbound aggregate base courses from Senegal (West Africa)," Open Journal of Civil Engineering, vol. 1, no. 1, pp. 1-6. 2011. doi: 10.4236/ojce.2011.11001

[14] F. Salour and S. Erlingsson, "Investigation of a pavement structural behaviour during spring thaw using falling weight deflectometer," Road Materials and Pavement Design, vol. 14, no. 1, pp. 141-158, Mar. 2013.

[15] Department of Highways, DH-S 205/2532 Standard Specification of Subbase Aggregate Material (in Thai), DOH, Bangkok, 1989.

[16] ASTM C136 / C136M-14, Standard Test Method for Sieve Analysis of Fine and Coarse Aggregates, ASTM International, West Conshohocken, PA, 2014.

[17] ASTM Standard C127-12, Standard Test Method for Density, Relative Density (Specific Gravity), and Absorption of Coarse Aggregate, ASTM International, West Conshohocken, PA, 2012.

[18] ASTM Standard C128-12, Standard Test Method for Density, Relative Density (Specific Gravity), and Absorption of Fine Aggregate, ASTM International, West Conshohocken, PA, 2012.

[19] ASTM D1557-12e1, Standard Test Methods for Laboratory Compaction Characteristics of Soil Using Modified Effort, ASTM International, West Conshohocken, PA, 2012.

[20] ASTM D1883 - 07e2, Standard Test Method for CBR (California Bearing Ratio) of Laboratory-Compacted Soils, ASTM International, West Conshohocken, PA, 2010.

[21] American Association of State Highway and Transportation Officials, AASHTO T 307-99 Standard Method of Test for Determining the Resilient Modulus of Soil and Aggregate Materials. Washington, DC: AASHTO, 2007.

[22] B. M. Das, "Soil Composition," in Principles of Geotechnical Engineering, 3 $3^{\text {rd }}$ ed. Boston, Massachusetts: PWS, 1994, ch. 2, pp. 31-66.

[23] Y. H. Huang, "Material Characterization," in Pavement Analysis and Design, $2^{\text {nd }}$ ed. Pearson Prentice Hall, 2004.

[24] A. T. Papagiannakis and E. A. Masad, "Characterization of Pavement Subgrades and Bases," in Pavement Design and Materials. John Wiley \& Sons, Inc., 2008. 